\title{
Obesity and male breast cancer: provocative parallels?
}

\author{
Matthew P. Humphries', V. Craig Jordan ${ }^{2}$ and Valerie Speirs ${ }^{1 *}$
}

\begin{abstract}
While rare compared to female breast cancer the incidence of male breast cancer (MBC) has increased in the last few decades. Without comprehensive epidemiological studies, the explanation for the increased incidence of MBC can only be speculated. Nevertheless, one of the most worrying global public health issues is the exponential rise in the number of overweight and obese people, especially in the developed world. Although obesity is not considered an established risk factor for MBC, studies have shown increased incidence among obese individuals. With this observation in mind, this article highlights the correlation between the increased incidence of MBC and the current trends in obesity as a growing problem in the $21^{\text {st }}$ century, including how this may impact treatment. With $\mathrm{MBC}$ becoming more prominent we put forward the notion that, not only is obesity a risk factor for MBC, but that increasing obesity trends are a contributing factor to its increased incidence.
\end{abstract}

Keywords: Aromatase, Aromatase inhibitor, Body mass index, Estrogen, Incidence, Male breast cancer, Obesity, Risk factor, Selective estrogen receptor modulator, Tamoxifen

\section{Background}

To our knowledge, male breast cancer $(\mathrm{MBC})$ was first reported in the medical literature in 1843 and described as the cause of death of five men in Paris from 1830 to 1840 [1]. Starting in the early 1800s, publications on $\mathrm{MBC}$ have steadily continued to increase from one or two each year to a peak of 68 publications in 2014. Data was obtained from PubMed using the search term "male breast cancer" in titles and abstracts from January 1st to December 31st, 2014 (search performed December 22nd, 2014).

According to the most recent estimates by The International Agency for Research on Cancer, a division of the World Health Organization, the global incidence of MBC stands at nearly 8,000 cases. For Europe, this equates to 3,750 cases of $\mathrm{MBC}$ [2]. In the US, the estimated number of cases in 2014 was expected to be 2,360, while the lifetime risk of men getting breast cancer is 1 in 1,000 [3]. These figures are significantly lower $(<1 \%)$ than the incidence of breast cancer in women, which represents $11.6 \%$ of the global cancer incidence in 2014 [4], with

\footnotetext{
* Correspondence: v.speirs@leeds.ac.uk

${ }^{1}$ Leeds Institute of Cancer and Pathology, University of Leeds, St James's University Hospital, Leeds LS9 7TF, UK

Full list of author information is available at the end of the article
}

approximately 232,000 and 425,000 women diagnosed with breast cancer annually in the US and Europe, respectively $[5,6]$. Men typically present, on average, 5 years later than women, commonly in the seventh decade [7-9].

\section{Increasing incidence of male breast cancer (MBC)}

Studies suggest that MBC incidence is rising [10-14]. A large population-based study of 2,537 men with breast cancer, analysed from the National Cancer Institute's Surveillance, Epidemiology and End Results (SEER) database, reported that over a 25 year period (1973-1998) the incidence of $\mathrm{MBC}$ increased significantly from 0.86 to 1.08 per 100,000 population in the US [15], with higher incidence in black than white men [16]. We have confirmed this in a more recent interrogation of the SEER dataset (Fig. 1) [17]. In terms of race, the rates of breast cancer are higher in black than white men while the reverse is true in female breast cancer (FBC) patients (Fig. 2). It should be noted from Fig. 2 that the incidence rates of FBC appear to plateau, which may be attributed to introduction of breast screening programs in the female population [18]. The higher rate of MBC observed in black men is at least partly due to more advanced disease presentation; studies have reported that a higher number of black $\mathrm{MBC}$ patients present with larger tumours 


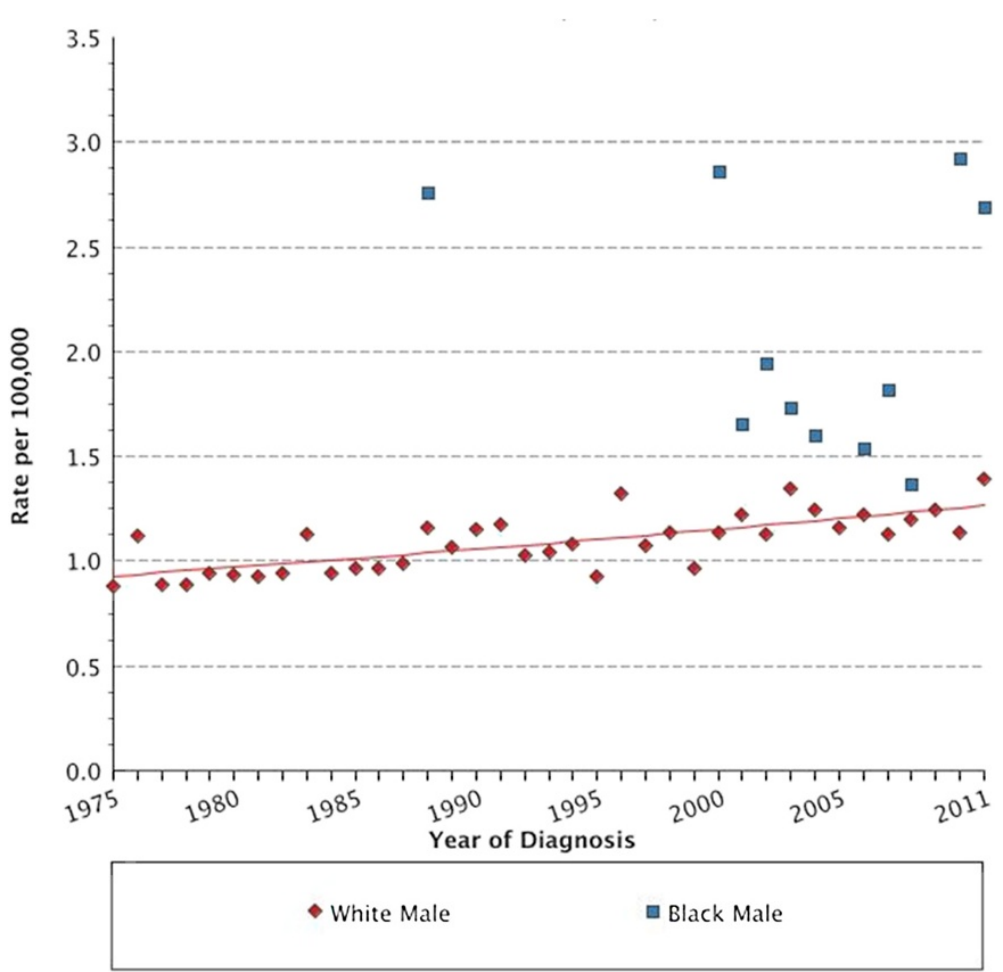

Fig. 1 Age-adjusted increasing incidence rates in white men over a 36 year period (Diamonds), with the incidence rates in black men over the same time period overlaid (Squares). Data obtained and graphs generated from SEER using the Fast Stats Registry, National Cancer Institute

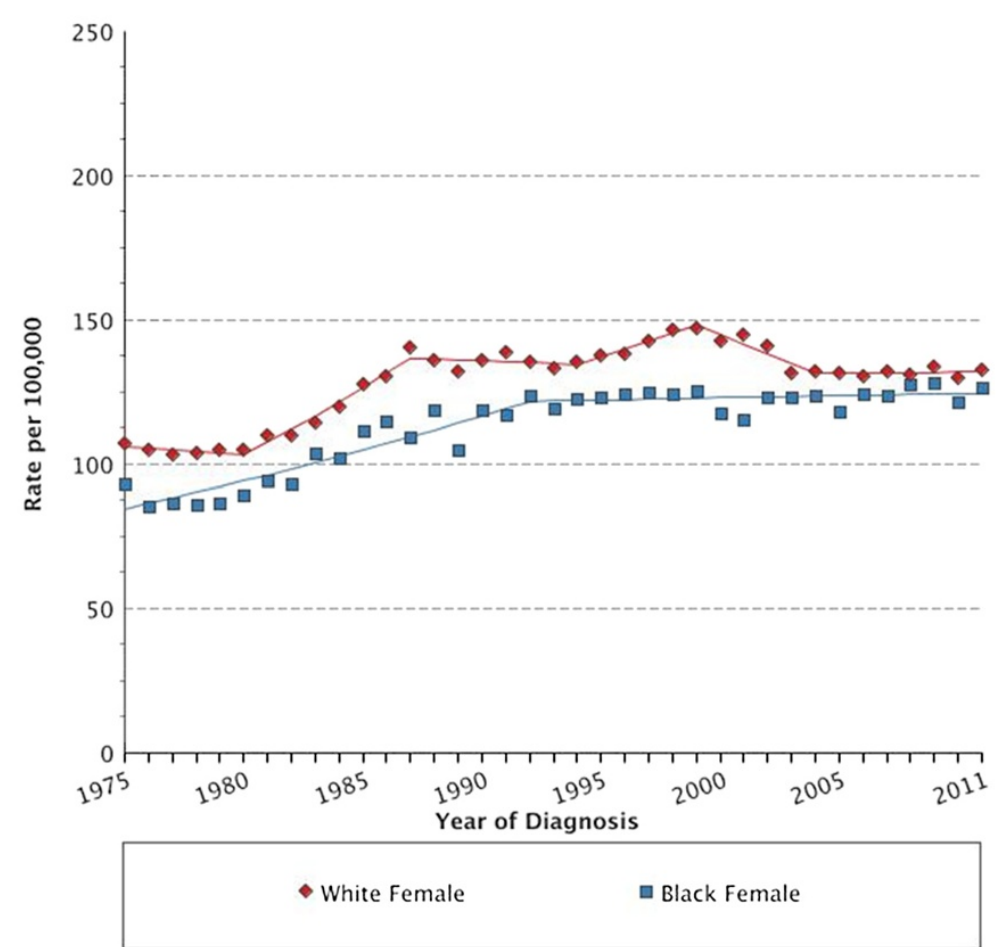

Fig. 2 Age-adjusted increasing incidence rates in white women over a 36 year period (Diamonds), with the incidence rates of black women over the same time period overlaid (Squares). Data obtained and graphs generated from SEER using the Fast Stats Registry, National Cancer Institute 
of higher grade, lymph node metastases, and lacking in hormone receptor expression, compared to white men [19]. Such racial disparity may be associated with biological/genetic predispositions or socioeconomic factors such as access to health care [16, 20, 21], highlighted recently by work addressing disparities between black and white men with early stage MBC [22].

While at first glance data from the UK (Cancer Research UK) suggests no change in age-standardised incidence from 1975-2011 [23], when grouped into decades, there is a rise in the average age-standardised incidence of 0.79 / 100,000 population in the $1975-1980$ to $0.85 / 100,000$ from 1990-2011 (Fig. 3).

It is possible that perceived increases in $\mathrm{MBC}$ incidence may simply reflect increased disease detection. Men are generally more health conscious than in previous generations, perhaps aided by increased awareness of breast cancer in general, and public education in MBC specifically, for example, through the John W Nick Foundation [24]; part of their mission statement is "to educate the world about the risk of breast cancer in men". Such campaigns may encourage men to present to a physician with breast-related symptoms, potentially increasing detection rates. Age, the single biggest risk factor for breast cancer, should also be considered; as an ageing population, increased $\mathrm{MBC}$ may well parallel increased longevity. However, increase in $\mathrm{MBC}$ is also reflected in age-standardised rates [15], which probably negates this argument.

\section{Obesity}

One of the most worrying global public health issues is the exponential rise in the number of overweight and obese people, which in a comprehensive study of 1,769 reports from 188 countries showed a rise from

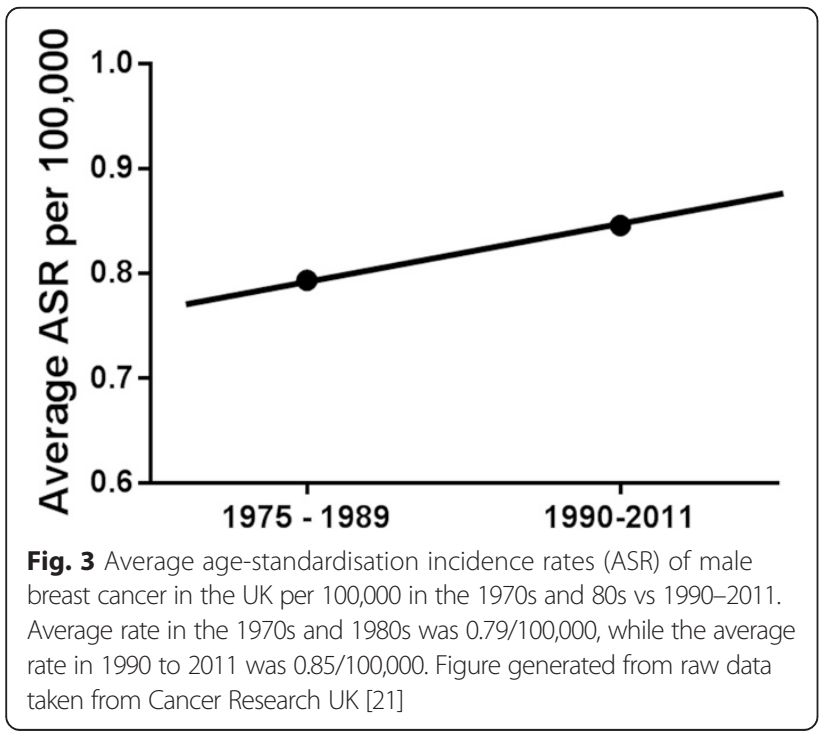

857 million in 1980 to 2.1 billion in 2013 [25] (Fig. 4); this has been described as "a global pandemic" [26, 27]. A key fact from these data is that, over this time period, more men than women were classified as overweight or obese in developed countries, whereas the opposite was true in developing countries [25]. The prevalence of overweight and obesity (overweight = body mass index (BMI, calculated as weight in kilograms divided by the square of height in meters) $\geq 25$; obese $=\mathrm{BMI} \geq 30$ ) were highest in the World Health Organization regions of the Americas (62\% for overweight in both sexes, and $26 \%$ for obesity); $65 \%$ of the world's population live in countries where overweight and obesity kills more people than underweight [28]. This trend shows no signs of reversing or even slowing as worldwide childhood obesity prevalence in 2010 was $6.7 \%$. Worryingly, in the United States, $20 \%$ of children are categorised as obese [29].

\section{Obesity and cancer}

It has long been known that obesity and the risk of cancer are linked. The International Agency for Research on Cancer and the World Cancer Research Fund reports show that common cancers in obese people are predominantly endometrial, esophageal adenocarcinoma, colorectal, postmenopausal breast, prostate, and renal $[30,31]$. Recent data from the US provided evidence that the number of white men considered overweight or obese was higher than that of black men (BMI $\geq 25$ ). However, when higher BMI was observed (BMI $\geq 30$ ) the converse was true. Furthermore, there were $55 \%$ more extremely obese black than white males (BMI $\geq 40$ ) [32]. Interestingly, this increase in male obesity in developed countries seems to mirror an increase in incidence of MBC [25, 33, 34]. This is also reflected by comparing data in Figs. 1 and 4, where respective increases in the

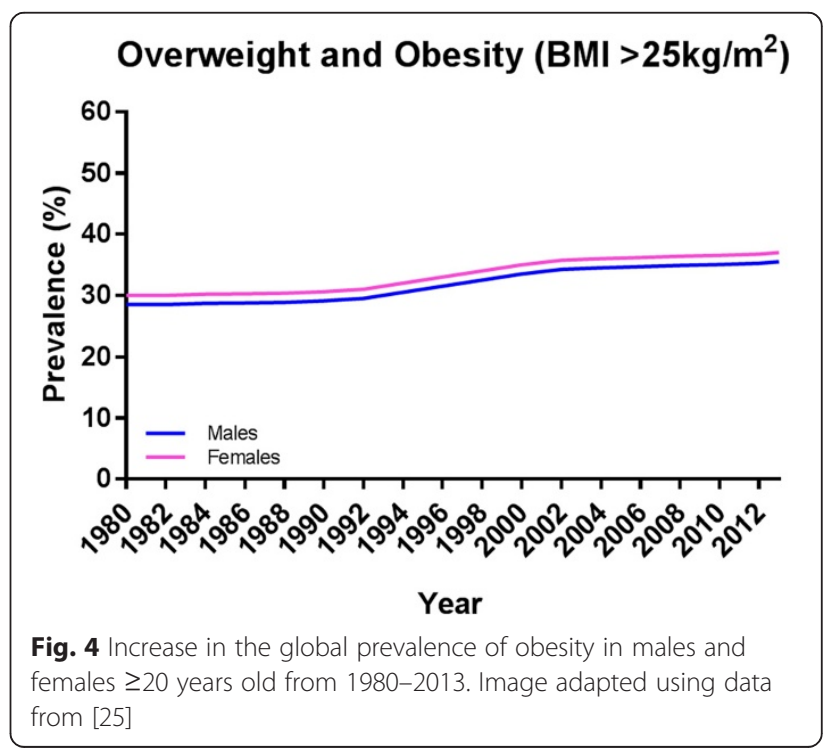


incidence of $\mathrm{MBC}$ and male obesity show parallel trends. In women, there is substantial and convincing evidence that weight gain at or around the menopause is a strong risk factor for breast cancer [35-39]. New evidence has emphasised this wherein obesity constituted an independent, adverse prognostic factor in node-positive FBC; this was particularly significant in estrogen receptor positive $(E R+)$ postmenopausal women [40]. Furthermore, increasing incidence of $\mathrm{FBC}$ is seen in developing countries where Western lifestyles are increasingly adopted [41]. It should be noted that, while obesity is a risk for FBC, other known risk factors include changes in reproductive practices, duration of breast feeding, and administration of hormone replacement therapy [19]. As these do not apply to men, could the parallel rises of obesity and MBC incidence be linked? The case has been made that the increased incidence is simply a pseudo observation due to an increase in detection [42], which may well be true; however, without comprehensive epidemiological studies the rationale for the increased $\mathrm{MBC}$ incidence can only be speculated.

\section{Known risk factors for male breast cancer (MBC)}

Risk factors associated with $\mathrm{MBC}$ include age, underlying genetics, including Klinefelter syndrome and BRCA2 mutations, radiation exposure, high estrogen levels, and liver cirrhosis as a result of excess alcohol consumption [7, 13-15, 33, 43-47]. However, a more recent publication has cast doubt on this latter association [48]. Gynecomastia is a relatively common benign enlargement of the male breast affecting an estimated $40-65 \%$ of males [49], with some studies considering this a risk factor for MBC development [33] by as much as 10-fold [14]. Interestingly, gynecomastia is often associated with male obesity $[50,51]$. Though not officially recognised as a risk factor for MBC, obesity has been highlighted by several studies as being significantly associated with MBC $[14,47,52]$. When one considers that adipose tissue contains aromatase, which converts testosterone to estrogen, increased levels of estrogen could produce an environment for cancer initiation in male breast tissue. Furthermore, conversion of testosterone to estradiol by aromatase in adipose tissue suppresses the release of luteinizing hormone, in turn leading to a reduction in testosterone production $[53,54]$. As a result, estrogen levels are significantly higher in older men than post-menopausal women [55]. Adipose tissue is a recognised site for the production of steroid hormones. Aromatase is one of several enzymes found in adipose tissue and is involved in estrogen biosynthesis by converting testosterone to estrogen (Fig. 5). In addition to aromatase, other steroid-metabolising enzymes, including $17 \beta$-hydroxysteroid dehydrogenases, play a role in increasing local estradiol concentrations [56]. Notably, localization of both aromatase and 17ß-hydroxysteroid dehydrogenase type 1 has been observed in MBC [57]. Adipose tissues are also recognised for their ability to secrete other factors, such as cytokines, which can enhance local estrogen biosynthesis that may exert local and/or systemic effects [58-64]. Recent data from the Male Breast Cancer Pooling Project supports the importance of estrogen in MBC etiology [65].

In the obese male, excess adipose tissue provides an environment conducive to increased estrogen production. Indeed, obese men produce as high as 2-fold more estrogen than men with average BMI [66] and males with very high BMI $(\geq 35)$ show markedly decreased testosterone levels and increased concentrations of estradiol in blood plasma [15, 67-71]. Thus, weight increase coupled with the declining levels of hormones in the ageing male could provide a hormone environment which helps promote the genesis of $\mathrm{MBC}$ in obese men. In addition, a study by Brinton et al. [14], which included results from the Male Breast Cancer Pooling Project, provided evidence from over 2,400 patients from 10 cohort studies indicating that obesity was a positive risk factor for $\mathrm{MBC}$; the authors observed a $30 \%$ increased risk in $\mathrm{MBC}$ from obesity. This increased risk was in agreement with studies in post-menopausal FBC demonstrating a similar increased risk in cancer [72-74].

\section{Survival rates and treatment for male breast cancer (MBC)}

MBC survival rates are generally assumed to be lower than in FBC, probably as a result of later diagnosis and the assumption that treatments developed through trials for FBC patients will perform equally well in men [75]. A study of over 13,000 men and almost 1.5 million women with breast cancer were reviewed over a 9 year period and showed 5 year survival rates of $74 \%$ for men and $83 \%$ for women [76]. The stage at diagnosis was a determining factor in survival rates for men compared to women. Latter stage diagnosis was more comparable, with 5 year survival in men at $16 \%$ and women at $19 \%$. [76]. A European study including almost 500,000 women and over 2,500 men concluded that survival was worse in men than women until adjusting for age, stage and treatment, whereby the opposite was true [19]. This is in agreement with other smaller studies [8, 77, 34]. Additionally, time to diagnosis is negatively impacted by the presence of obesity [78-80]. This is due, but not limited to, difficulties in self-detection and possible embarrassment in seeking medical consultation due to excess weight. Further, obese patients are more likely to postpone clinical appointments for 3 months following first symptom occurrence [81]. Furthermore, obese patients undergo MRI and ultrasound less often when compared to those within a normal weight range [82]. All of the 


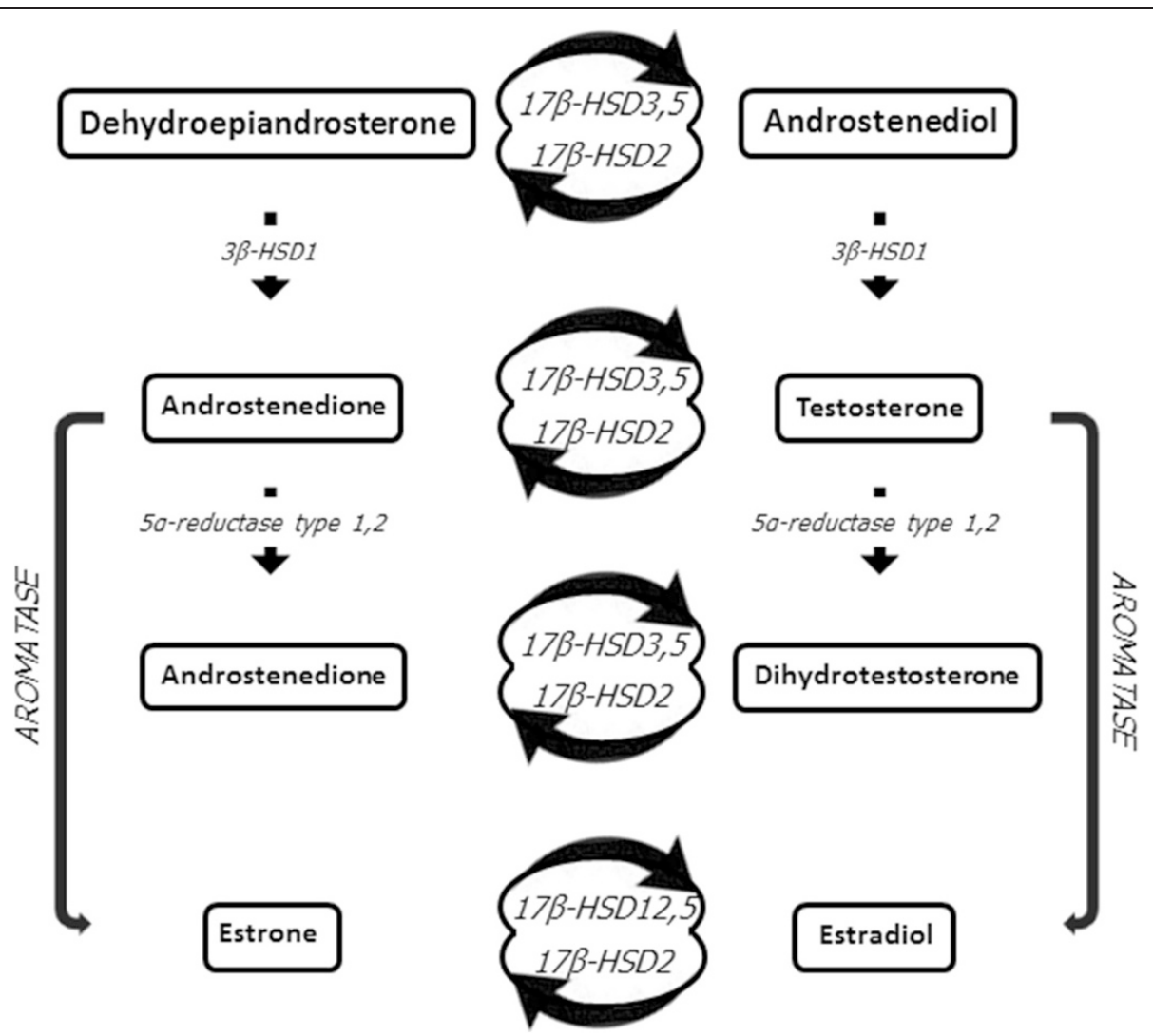

Fig. 5 Pathways of steroid hormone metabolism in adipose tissue. Bold boxes highlight steroid hormones. Italics denote enzymes with

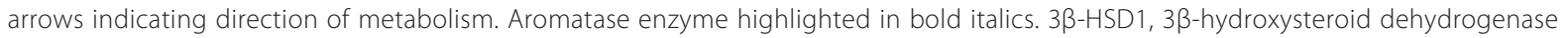

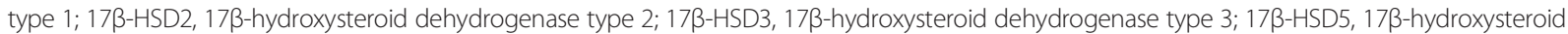
dehydrogenase type 5; 17 -HSD12, 17 -hydroxysteroid dehydrogenase type 12. Image was compiled by the author by drawing on information from $[56,116,117]$

above may lead to more advanced disease at presentation which could impact survival.

The current standard of care for $\mathrm{MBC}$ patients is tamoxifen [83-87]. The case could be made that, when obese males present with $\mathrm{MBC}$, aromatase inhibitors (AIs) should be advocated. Indeed, some studies have encouraged this for ER+ MBC patients in combination with tamoxifen [88]. However, this contradicts data from the ATAC (Arimidex, Tamoxifen, Alone or in Combination) trial, which compared the efficacy of AIs with tamoxifen, alone or in combination [89], where the combination treatment arm was closed after an initial analyses at 33 and 47 months of follow-up due to low efficacy [89, 90]. Granted, the ATAC trial was female-only but with growing evidence of biological differences between MBC and FBC [57, 91-95], the outcome may well be different in men. However, there are difficulties in accruing for a genderspecific trial, as highlighted by the withdrawal of a phase II study (SWOG-S0511) due to poor accrual of MBC patients (ClinicalTrials.gov. Trial record: NCT00217659). Nevertheless, analysis of 257 hormone-receptor-positive
German MBC patients treated with tamoxifen $(\mathrm{n}=207)$ or AIs $(\mathrm{n}=50)$ showed the overall survival was significantly better after adjuvant treatment with tamoxifen compared to AI [96].

No clinical studies we are aware of have reported on the treatment of obese $\mathrm{MBC}$ patients with tamoxifen and AIs. Obesity in MBC patients should be considered in the context of treatment. Treatment with AIs alone have been shown to increase LH and FSH levels, which may be deleterious due to increased substrate for aromatisation in some MBC patients and further exacerbate the situation [97-100]. It has been hypothesised that introducing a gonadotropin-releasing hormone analogue with AIs, should tumour progression be seen, could counteract the activity of the hormonal feedback loop [88].

Additionally, functional single nucleotide polymorphisms (SNPs) exist in the aromatase gene that can improve how breast cancer patients respond to AIs. These alterations in the wild-type and variant sequences result in different DNA protein binding capabilities and displayed different transcriptional activity, resulting in atypical estrogen 
production [101]. Furthermore, there is early evidence that altered estrogen levels can be modified by changes in BMI in patients with these SNPs in aromatase [102]. These data highlight the need for further experimental studies focusing on the biological consequences of obesity and how this may impact on MBC treatment.

It is pertinent at this juncture to bring to light the connection between cholesterol and its oxysterol metabolite 27-hydroxycholesterol $(27 \mathrm{HC})$ in the context of obesity. 27HC is a recognised selective ER modulator (SERM) and was the first endogenous ligand demonstrated as having SERM activity [103]. The conversion of $27 \mathrm{HC}$ from the hydroxylation of cholesterol is achieved by the cytochrome p450 enzyme, CYP27A1 [104]. The ligand binding of $27 \mathrm{HC}$ to ER in ER+ breast cancer has been shown to induce cell proliferation $[105,106]$. As $\mathrm{MBC}$ is overwhelmingly ER+ it follows logically that patients with higher $27 \mathrm{HC}$ provide a favourable growth environment for tumour development. Circulating levels of $27 \mathrm{HC}$ correlate with cholesterol levels; however, in the obese patient, cholesterol is often much higher and consequently an increase in $27 \mathrm{HC}$ is reported [107]. The consequence for the obese male is that increased $27 \mathrm{HC}$ levels, as a direct consequence of higher cholesterol, could contribute to the development of $\mathrm{MBC}$ via the mitogenic signalling of $27 \mathrm{HC}$ in the male breast.

\section{Conclusions}

While the case for linking obesity to $\mathrm{MBC}$ is strong, a number of other contributing factors should be discussed. Changes in the Western diet over the past several decades may not only have shifted the average body composition towards a more obese/overweight state [108], but also changed the dietary composition towards a high intake of refined carbohydrates, added sugars, fats, and animalsource foods. Increased body awareness may result in earlier visits to GPs than in previous generations to investigate a problem, which will contribute to increased detection rates. Exposure to so-called environmental oestrogens via diet, household products, perfumes and deodorants are considered by some as risk factors for breast cancer development as collectively, prolonged exposure to low doses of these compounds could provide a significant estrogenic stimulus to target tissues [109-112]. However, there are no substantive data to support this and this would not be gender-specific.

Based on current evidence, we propose that the incidence trends of both MBC and obesity are inextricably linked and, as others have postulated [14, 47, 52], obesity should be considered as a risk factor for MBC in the same way this has recently been proposed for prostate cancer [113]. When considering treatment, a contextual perspective should be adopted with the atypical microenvironment, created and exacerbated by obesity, taken into account. Obesity is recognised as a preventable condition and sufficient weight loss has been shown to flip the ratio of hormones to normal physiological levels in obese men (BMI $\geq 30)$ [114, 115]. Peripheral aromatisation of androgens in adipose tissue of obese men could provide a hormonal milieu which encourages tumour development. While the risks of MBC from obesity have not been quantified, we propose that men at risk from $\mathrm{MBC}$, e.g., those with BRCA2 mutations or suffering from Klinefelter syndrome, should be made aware of the relative risk between MBC and obesity to take pre-emptive measures to reduce this risk.

\begin{abstract}
Abbreviations
27HC: 27-hydroxycholesterol; Al: Aromatase inhibitors; BMl: Body mass index; ER: Estrogen receptor; FBC: Female breast cancer; MBC: Male breast cancer; SEER: Surveillance, Epidemiology, and End Results; SERM: Selective estrogen receptor modulator; SNP: Single nucleotide polymorphisms.
\end{abstract}

\section{Competing interests}

The authors declare that they have no competing interests.

\section{Authors' contributions}

All authors conceived the study. $\mathrm{MH}$ conducted the article searches. $\mathrm{MH}$ and VS produced the initial draft. All authors were involved in the interpretation and writing of the review. VS and CJ critically revised the manuscript. All authors approved the final version of the paper.

\section{Acknowledgments}

Our Male Breast Cancer Programme is supported by Yorkshire Cancer Research, Breast Cancer Campaign, and The Breast Cancer Research Trust.

\section{Author details}

${ }^{1}$ Leeds Institute of Cancer and Pathology, University of Leeds, St James's University Hospital, Leeds LS9 7TF, UK. '2Department of Breast Medical Oncology and Molecular and Cellular Oncology, MD Anderson Cancer Center, Houston, TX 77030, USA.

Received: 3 March 2015 Accepted: 19 May 2015

Published online: 04 June 2015

\section{References}

1. Tanchou. Statistics of cancer. Lancet. 1843;40:649-50. doi:10.1016/ S0140-6736(02)87094-5.

2. Ferlay J BF, Steliarova-Foucher E, Forman D. Cancer incidence in five continents, Cl5plus: IARC CancerBase No. 9. 2014. http://ci5.iarc.fr. Accessed 19 Dec 2014.

3. American Cancer Society. Cancer facts and figures 2014. Atlanta, GA: American Cancer Society; 2014. http://www.cancer.org/acs/groups/content/ @research/documents/webcontent/acspc-042151.pdf. Accessed 16 Dec 2014.

4. Ferlay J SI, Ervik M, Dikshit R, Eser S, Mathers C, Rebelo M, et al. GLOBOCAN 2012 v1.0. Cancer incidence and mortality worldwide: IARC CancerBase No. 11. 2013. http://globocan.iarc.fr. Accessed 29 Jul 2014.

5. Ferlay J, Steliarova-Foucher E, Lortet-Tieulent J, Rosso S, Coebergh JWW, Comber $\mathrm{H}$, et al. Cancer incidence and mortality patterns in Europe: Estimates for 40 countries in 2012. Eur J Cancer. 2013;49:1374-403. doi:10.1016/j.ejca.2012.12.027.

6. Ly D, Forman D, Ferlay J, Brinton LA, Cook MB. An international comparison of male and female breast cancer incidence rates. Int J Cancer. 2013;132:1918-26. doi:10.1002/ijc.27841.

7. Giordano SH, Buzdar AU, Hortobagyi GN. Breast cancer in men. Ann Intern Med. 2002;137:678-87. doi:10.7326/0003-4819-137-8-200210150-00013.

8. Scott-Conner CE, Jochimsen PR, Menck HR, Winchester DJ. An analysis of male and female breast cancer treatment and survival among demographically identical pairs of patients. Surgery. 1999;126:775-80. Discussion 80-1.

9. Dabakuyo TS, Dialla O, Gentil J, Poillot ML, Roignot P, Cuisenier J, et al. Breast cancer in men in Cote d'Or (France): epidemiological characteristics, treatments and prognostic factors. Eur J Cancer Care. 2012;21:809-16. doi:10.1111/j.1365-2354.2012.01365.x. 
10. White J, Kearins O, Dodwell D, Horgan K, Hanby A, Speirs V. Male breast carcinoma: increased awareness needed. Breast Cancer Res. 2011;13:219.

11. Hodgson NC, Button JH, Franceschi D, Moffat FL, Livingstone AS. Male breast cancer: is the incidence increasing? Ann Surg Oncol. 2004;11:751-5. doi:10.1245/aso.2004.01.001.

12. Contractor KB, Kaur K, Rodrigues GS, Kulkarni DM, Singhal H. Male breast cancer: is the scenario changing. World J Surg Oncol. 2008;6:58. doi:10.1186/1477-7819-6-58.

13. Speirs $V$, Shaaban AM. The rising incidence of male breast cancer. Breast Cancer Res Treat. 2009;115:429-30. doi:10.1007/s10549-008-0053-y.

14. Brinton LA, Cook MB, McCormack V, Johnson KC, Olsson H, Casagrande JT, et al. Anthropometric and hormonal risk factors for male breast cancer: male breast cancer pooling project results. J Natl Cancer Inst. 2014;106:djt465. doi:10.1093/jnci/djt465.

15. Giordano S, Cohen D, Buzdar A, Perkins G, Hortobagyi G. Breast carcinoma in men: a population-based study. Cancer. 2004;101:51-7.

16. Anderson WF, Althuis MD, Brinton LA, Devesa SS. Is male breast cancer similar or different than female breast cancer? Breast Cancer Res Treat. 2004;83:77-86. doi:10.1023/B:BREA.0000010701.08825.2d.

17. SEER. Surveillance Epidemiology and End Results (SEER). Program Surveillance Research Program, Surveillance Systems Branch. 2015. NCl. www.seercancer.gov. Accessed 13 Dec 2014.

18. Shin JY, Kachnic LA, Hirsch AE. The impact of race in male breast cancer treatment and outcome in the United States: a population-based analysis of 4,279 patients. Int J Breast Cancer. 2014;2014:685842. doi:10.1155/2014/685842.

19. Miao H, Verkooijen HM, Chia KS, Bouchardy C, Pukkala E, Laronningen S, et al. Incidence and outcome of male breast cancer: an international population-based study. J Clin Oncol. 2011;29:4381-6. doi:10.1200/jco.2011.36.8902.

20. Chavez-Macgregor M, Clarke CA, Lichtensztajn D, Hortobagyi GN, Giordano SH. Male breast cancer according to tumor subtype and race: a population-based study. Cancer. 2013;119:1611-7. doi:10.1002/cncr.27905.

21. O'Malley CD, Prehn AW, Shema SJ, Glaser SL. Racial/ethnic differences in survival rates in a population-based series of men with breast carcinoma. Cancer. 2002;94:2836-43. doi:10.1002/cncr.10521.

22. Sineshaw HM, Freedman RA, Ward EM, Flanders WD, Jemal A. Black/white disparities in receipt of treatment and survival among men with early-stage breast cancer. J Clin Oncol. 2015. Ahead of print. doi:10.1200/jco.2014.60.5584.

23. CRUK. Breast cancer incidence in males. 2014. http://www.cancerresearchuk.org/ cancer-info/cancerstats/types/breast/incidence/uk-breast-cancer-incidencestatistics\#source1. Accessed 28 Jan 2015.

24. John W. Nick Foundation. Sebastian, FL. 2015. https://www.malebreastcancer.org/. Accessed 14 May 2015.

25. Ng M, Fleming T, Robinson M, Thomson B, Graetz N, Margono C, et al. Global, regional, and national prevalence of overweight and obesity in children and adults during 1980-2013: a systematic analysis for the Global Burden of Disease Study 2013. Lancet. 2014;384:766-81. doi:10.1016/S0140-6736(14)60460-8.

26. Roth J, Qiang X, Marban SL, Redelt H, Lowell BC. The obesity pandemic: where have we been and where are we going? Obes Res. 2004;12:88S-101. doi:10.1038/oby.2004.273.

27. Swinburn BA, Sacks G, Hall KD, McPherson K, Finegood DT, Moodie ML, et al. The global obesity pandemic: shaped by global drivers and local environments. Lancet. 2011;378:804-14. doi:10.1016/s0140-6736(11)60813-1.

28. Annex A. World Health Organization. Obesity and overweight fact sheet. 2011 http://www.who.int/mediacentre/factsheets/fs311/en/. Accessed 20 Dec 2014

29. Haidar YM, Cosman BC. Obesity epidemiology. Clin Colon Rectal Surg. 2011:24:205-10. doi:10.1055/s-0031-1295684.

30. De Pergola G, Silvestris F. Obesity as a major risk factor for cancer. J Obes. 2013;2013:11. doi:10.1155/2013/291546.

31. AICR. World Cancer Research Fund. Food, nutrition, physical activity, and the prevention of cancer: a global perspective. Washington, DC. 2nd Edition. http://discovery.ucl.ac.uk/4841/1/4841.pdf. 2007. Accessed 6 Jan 2015.

32. Ogden CL, Carroll MD, Kit BK, Flegal KM. Prevalence of childhood and adult obesity in the United States, 2011-2012. JAMA. 2014;311:806-14. doi:10.1001/jama.2014.732.

33. White J, Kearins O, Dodwell D, Horgan K, Hanby AM, Speirs V. Male breast carcinoma: increased awareness needed. Breast Canc Res. 2011;13:219. doi:10.1186/bcr2930.

34. Shaaban A, Ball G, Brannan R, Cserni G, Di Benedetto A, Dent J, et al. A comparative biomarker study of 514 matched cases of male and female breast cancer reveals gender-specific biological differences. Breast Cancer Res Treat. 2012;133:949-58. doi:10.1007/s10549-011-1856-9.

35. La Vecchia C, Negri E, Franceschi S, Talamini R, Bruzzi P, Palli D, et al. Body mass index and post-menopausal breast cancer: an age-specific analysis. $\mathrm{Br}$ J Cancer. 1997;75:441-4.

36. Trentham-Dietz A, Newcomb PA, Storer BE, Longnecker MP, Baron J, Greenberg ER, et al. Body size and risk of breast cancer. Am J Epidemiol. 1997;145:1011-9.

37. Key TJ, Appleby PN, Reeves GK, Roddam A, Dorgan JF, Longcope C, et al. Body mass index, serum sex hormones, and breast cancer risk in postmenopausal women. J Natl Cancer Inst. 2003;95:1218-26.

38. Phipps Al, Chlebowski RT, Prentice R, McTiernan A, Stefanick ML, Wactawski-Wende J, et al. Body size, physical activity, and risk of triple-negative and estrogen receptor-positive breast cancer. Cancer Epidemiol Biomarkers Prev. 2011;20:454-63. doi:10.1158/1055-9965.epi-10-0974.

39. Monninkhof EM, van der Schouw YT, Peeters PH. Early age at menopause and breast cancer: are leaner women more protected? A prospective analysis of the Dutch DOM cohort. Breast Cancer Res Treat. 1999;55:285-91.

40. Scholz C, Andergassen U, Hepp P, Schindlbeck C, Friedl TW, Harbeck N, et al. Obesity as an independent risk factor for decreased survival in node-positive high-risk breast cancer. Breast Cancer Res Treat. 2015. Ahead of print. doi:10.1007/s10549-015-3422-3.

41. Jemal A, Center MM, DeSantis C, Ward EM. Global patterns of cancer incidence and mortality rates and trends. Cancer Epidemiol Biomarkers Prev. 2010;19:1893-907. doi:10.1158/1055-9965.epi-10-0437.

42. Anderson WF, Devesa SS. Breast carcinoma in men. Cancer. 2005;103:432-3. doi:10.1002/cncr.20797. Author reply 3.

43. Misra SP, Misra V, Dwivedi M. Cancer of the breast in a male cirrhotic: is there an association between the two? Am J Gastroenterol. 1996:91:380-2.

44. Guenel P, Cyr D, Sabroe S, Lynge E, Merletti F, Ahrens W, et al. Alcohol drinking may increase risk of breast cancer in men: a European population-based case-control study. Cancer Causes Contro. 2004;15:571-80. doi:10.1023/b:caco.0000036154.18162.43

45. Memon MA, Donohue JH. Male breast cancer. Br J Surg. 1997:84:433-5.

46. Alali L, Honarpisheh H, Shaaban A, Speirs V. Conditions of the male breast: gynaecomastia and male breast cancer (Review). Mol Med Rep. 2010;3:21-6. doi:10.3892/mmr_00000213.

47. Brinton LA, Richesson DA, Gierach GL, Lacey Jr JV, Park Y, Hollenbeck AR, et al. Prospective evaluation of risk factors for male breast cancer. J Natl Cancer Inst. 2008;100:1477-81. doi:10.1093/jnci/djn329.

48. Cook MB, Guenel P, Gapstur SM, van den Brandt PA, Michels KB, Casagrande JT, et al. Tobacco and alcohol in relation to male breast cancer: an analysis of the male breast cancer pooling project consortium. Cancer Epidemiol Biomarkers Prev. 2015;24:520-31. doi:10.1158/1055-9965.epi-14-1009.

49. Bembo SA, Carlson HE. Gynecomastia: its features, and when and how to treat it. Cleve Clin J Med. 2004;71:511-7.

50. Rosen $\mathrm{H}$, Webb ML, DiVasta AD, Greene AK, Weldon $C B$, Kozakewich $H$, et al Adolescent gynecomastia: not only an obesity issue. Ann Plast Surg. 2010;64:688-90. doi:10.1097/SAP.0b013e3181dba827.

51. Ersoz H, Onde ME, Terekeci H, Kurtoglu S, Tor H. Causes of gynaecomastia in young adult males and factors associated with idiopathic gynaecomastia. Int J Androl. 2002;25:312-6.

52. Ewertz M, Holmberg L, Tretli S, Pedersen BV, Kristensen A. Risk factors for male breast cancer - a case-control study from Scandinavia. Acta Oncologica (Stockholm, Sweden). 2001;40:467-71.

53. Finkelstein JS, O'Dea LS, Whitcomb RW, Crowley Jr WF. Sex steroid control of gonadotropin secretion in the human male. II. Effects of estradiol administration in normal and gonadotropin-releasing hormone-deficient men. J Clin Endocrinol Metab. 1991;73:621-8. doi:10.1210/jcem-73-3-621.

54. Hayes FJ, Seminara SB, Decruz S, Boepple PA, Crowley Jr WF. Aromatase inhibition in the human male reveals a hypothalamic site of estrogen feedback J Clin Endocrinol Metab. 2000:85:3027-35. doi:10.1210/jcem.85.9.6795.

55. Vermeulen A, Kaufman JM, Goemaere S, van Pottelberg I. Estradiol in elderly men. Aging Male. 2002;5:98-102.

56. Tchernof A, Mansour MF, Pelletier M, Boulet MM, Nadeau M, Luu-The V. Updated survey of the steroid-converting enzymes in human adipose tissues. J Steroid Biochem Mol Biol. 2015;147c:56-69. doi:10.1016/j.jsbmb.2014.11.011.

57. Takagi K, Moriya T, Kurosumi M, Oka K, Miki Y, Ebata A, et al. Intratumoral estrogen concentration and expression of estrogen-induced genes in male breast carcinoma: comparison with female breast carcinoma. Horm Cancer. 2013;4:1-11. doi:10.1007/s12672-012-0126-6. 
58. Speirs V, Green AR, White MC. A comparative study of cytokine gene transcripts in normal and malignant breast tissue and primary cell cultures derived from the same tissue samples. Int J Cancer. 1996;66:551-6. doi:10.1002/(sici)1097-0215(19960516)66:4<551::aid-ijc21>3.0.co;2-9.

59. Speirs V, Adams EF, White MC. The anti-estrogen tamoxifen blocks the stimulatory effects of interleukin-6 on 17 beta-hydroxysteroid dehydrogenase activity in MCF-7 cells. J Steroid Biochem Mol Biol. 1993;46:605-11.

60. Vona-Davis L, Rose DP. Adipokines as endocrine, paracrine, and autocrine factors in breast cancer risk and progression. Endocr Relat Cancer. 2007:14:189-206. doi:10.1677/erc-06-0068.

61. Schaffler A, Scholmerich J, Buechler C. Mechanisms of disease: adipokines and breast cancer - endocrine and paracrine mechanisms that connect adiposity and breast cancer. Nat Clin Pract Endocrinol Metab. 2007;3:345-54. doi:10.1038/ncpendmet0456.

62. Harvey AE, Lashinger LM, Hursting SD. The growing challenge of obesity and cancer: an inflammatory issue. Ann N Y Acad Sci. 2011;1229:45-52. doi:10.1111/j.1749-6632.2011.06096.x.

63. Wang YY, Lehuede C, Laurent V, Dirat B, Dauvillier S, Bochet L, et al. Adipose tissue and breast epithelial cells: a dangerous dynamic duo in breast cancer. Cancer Lett. 2012;324:142-51. doi:10.1016/j.canlet.2012.05.019.

64. Cleary MP. Impact of obesity on development and progression of mammary tumors in preclinical models of breast cancer. J Mammary Gland Biol Neoplasia. 2013;18:333-43. doi:10.1007/s10911-013-9300-x.

65. Brinton LA, Key TJ, Kolonel LN, Michels KB, Sesso HD, Ursin G, et al. Prediagnostic sex steroid hormones in relation to male breast cancer risk. J Clin Oncol. 2015. Ahead of print. doi:10.1200/jco.2014.59.1602.

66. Schneider G, Kirschner MA, Berkowitz R, Ertel NH. Increased estrogen production in obese men. J Clin Endocrinol Metab. 1979;48:633-8. doi:10.1210/jcem-48-4-633.

67. Kley HK, Edelmann P, Kruskemper HL. Relationship of plasma sex hormones to different parameters of obesity in male subjects. Metabolism. 1980;29:1041-5.

68. Strain GW, Zumoff B, Kream J, Strain JJ, Deucher R, Rosenfeld RS, et al. Mild hypogonadotropic hypogonadism in obese men. Metabolism. 1982;31:871-5.

69. Fui MN, Dupuis P, Grossmann M. Lowered testosterone in male obesity: mechanisms, morbidity and management. Asian J Androl. 2014;16:223-31. doi:10.4103/1008-682x.122365.

70. Derby CA, Zilber S, Brambilla D, Morales KH, McKinlay JB. Body mass index, waist circumference and waist to hip ratio and change in sex steroid hormones: the Massachusetts Male Ageing Study. Clin Endocrinol (Oxf). 2006;65:125-31. doi:10.1111/j.1365-2265.2006.02560.x.

71. Rohrmann S, Shiels MS, Lopez DS, Rifai N, Nelson WG, Kanarek N, et al. Body fatness and sex steroid hormone concentrations in US men: results from NHANES III. Cancer Causes Contro. 2011;22:1141-51. doi:10.1007/s10552-011-9790-z.

72. Ahn J, Schatzkin A, Lacey Jr JV, Albanes D, Ballard-Barbash R, Adams KF, et al. Adiposity, adult weight change, and postmenopausal breast cancer risk. Arch Intern Med. 2007;167:2091-102. doi:10.1001/archinte.167.19.2091.

73. Cheraghi Z, Poorolajal J, Hashem T, Esmailnasab N, Doosti IA. Effect of body mass index on breast cancer during premenopausal and postmenopausal periods: a meta-analysis. PLoS One. 2012;7:e51446. doi:10.1371/journal.pone.0051446.

74. Hartz A, He T. Cohort study of risk factors for breast cancer in post menopausal women. Epidemiol Health. 2013;35:e2013003. doi:10.4178/epih/e2013003.

75. Fentiman IS, Fourquet A, Hortobagyi GN. Male breast cancer. Lancet. 2006:367:595-604. doi:10.1016/s0140-6736(06)68226-3.

76. Greif JM, Pezzi CM, Klimberg VS, Bailey L, Zuraek M. Gender differences in breast cancer: analysis of 13,000 breast cancers in men from the National Cancer Data Base. Ann Surg Oncol. 2012;19:3199-204. doi:10.1245/s10434-012-2479-z.

77. El-Tamer MB, Komenaka IK, Troxel A, Li H, Joseph KA, Ditkoff BA, et al. Men with breast cancer have better disease-specific survival than women. Arch Surg. 2004;139:1079-82. doi:10.1001/archsurg.139.10.1079.

78. Cui Y, Whiteman MK, Flaws JA, Langenberg P, Tkaczuk KH, Bush TL. Body mass and stage of breast cancer at diagnosis. Int J Cancer. 2002;98:279-83.

79. Majed B, Moreau T, Senouci K, Salmon RJ, Fourquet A, Asselain B. Is obesity an independent prognosis factor in woman breast cancer? Breast Cancer Res Treat. 2008;111:329-42. doi:10.1007/s10549-007-9785-3.

80. Haakinson DJ, Leeds SG, Dueck AC, Gray RJ, Wasif N, Stucky CC, et al. The impact of obesity on breast cancer: a retrospective review. Ann Surg Oncol. 2012;19:3012-8. doi:10.1245/s10434-012-2320-8.

81. Arndt V, Sturmer T, Stegmaier C, Ziegler H, Dhom G, Brenner H. Patient delay and stage of diagnosis among breast cancer patients in Germany - a population based study. Br J Cancer. 2002;86:1034-40. doi:10.1038/ sj.bjc.6600209.

82. Deglise C, Bouchardy C, Burri M, Usel M, Neyroud-Caspar I, Vlastos G, et al. Impact of obesity on diagnosis and treatment of breast cancer. Breast Cancer Res Treat. 2010;120:185-93. doi:10.1007/s10549-009-0459-1.

83. Jordan VC. Tamoxifen as the first targeted long-term adjuvant therapy for breast cancer. Endocr Relat Cancer. 2014;21:R235-46. doi:10.1530/erc-14-0092.

84. Ribeiro G, Swindell R. Adjuvant tamoxifen for male breast cancer (MBC). Br J Cancer. 1992;65:252-4.

85. Baojiang L, Tingting L, Gang L, Li Z. Male breast cancer: a retrospective study comparing survival with female breast cancer. Oncol Lett. 2012;4:642-6. doi:10.3892/ol.2012.809.

86. Zagouri F, Sergentanis TN, Chrysikos D, Dimopoulos MA, Psaltopoulou T. Fulvestrant and male breast cancer: a pooled analysis. Breast Cancer Res Treat. 2015;149:269-75. doi:10.1007/s10549-014-3240-Z.

87. Wenhui Z, Shuo L, Dabei T, Ying P, Zhipeng W, Lei Z, et al. Androgen receptor expression in male breast cancer predicts inferior outcome and poor response to tamoxifen treatment. Eur J Endocrinol. 2014;171:527-33. doi:10.1530/eje-14-0278.

88. Maugeri-Sacca M, Barba M, Vici P, Pizzuti L, Sergi D, De Maria R, et al. Aromatase inhibitors for metastatic male breast cancer: molecular, endocrine, and clinical considerations. Breast Cancer Res Treat. 2014;147:227-35. doi:10.1007/s10549-014-3087-3.

89. Baum M, Budzar AU, Cuzick J, Forbes J, Houghton JH, Klijn JG, et al. Anastrozole alone or in combination with tamoxifen versus tamoxifen alone for adjuvant treatment of postmenopausal women with early breast cancer: first results of the ATAC randomised trial. Lancet. 2002;359:2131-9.

90. Baum M, Buzdar A, Cuzick J, Forbes J, Houghton J, Howell A, et al. Anastrozole alone or in combination with tamoxifen versus tamoxifen alone for adjuvant treatment of postmenopausal women with early-stage breast cancer: results of the ATAC (Arimidex, Tamoxifen Alone or in Combination) trial efficacy and safety update analyses. Cancer. 2003;98:1802-10. doi:10.1002/cncr.11745

91. Johansson I, Killander F, Linderholm B, Hedenfalk I. Molecular profiling of male breast cancer - Lost in translation? Int J Biochem Cell Biol. 2014:53:526-35. doi:10.1016/j.biocel.2014.05.007.

92. Kornegoor R, Verschuur-Maes AH, Buerger $H$, Hogenes MC, de Bruin PC, Oudejans JJ, et al. Molecular subtyping of male breast cancer by immunohistochemistry. Mod Pathol. 2012;25:398-404. doi:10.1038/ modpathol.2011.174.

93. Callari M, Cappelletti V, De Cecco L, Musella V, Miodini P, Veneroni S, et al. Gene expression analysis reveals a different transcriptomic landscape in female and male breast cancer. Breast Cancer Res Treat. 2011;127:601-10. doi:10.1007/s10549-010-1015-8.

94. Johansson I, Nilsson C, Berglund P, Strand C, Jonsson G, Staaf J, et al. High-resolution genomic profiling of male breast cancer reveals differences hidden behind the similarities with female breast cancer. Breast Cancer Res Treat. 2011;129:747-60. doi:10.1007/s10549-010-1262-8.

95. Pinto R, De Summa S, Danza K, Popescu O, Paradiso A, Micale L, et al. MicroRNA expression profiling in male and female familial breast cancer. Br J Cancer. 2014;111:2361-8. doi:10.1038/bjc.2014.535.

96. Eggemann H, Ignatov A, Smith BJ, Altmann U, von Minckwitz G, Rohl FW, et al. Adjuvant therapy with tamoxifen compared to aromatase inhibitors for 257 male breast cancer patients. Breast Cancer Res Treat. 2013;137:465-70. doi:10.1007/s10549-012-2355-3.

97. Bhatnagar AS, Müller P, Schenkel L, Trunet PF, Beh I, Schieweck K. Inhibition of estrogen biosynthesis and its consequences on gonadotrophin secretion in the male. J Steroid Biochem Mol Biol. 1992;41:437-43. doi:10.1016/0960-0760(92)90369-T.

98. Trunet PF, Mueller P, Bhatnagar AS, Dickes I, Monnet G, White G. Open dose-finding study of a new potent and selective nonsteroidal aromatase inhibitor, CGS 20 267, in healthy male subjects. J Clin Endocrinol Metab. 1993;77:319-23. doi:10.1210/jcem.77.2.8345034.

99. Mauras N, O'Brien KO, Klein KO, Hayes V. Estrogen suppression in males: metabolic effects. J Clin Endocrinol Metab. 2000;85:2370-7. doi:10.1210/jcem.85.7.6676.

100. Doyen J, Italiano A, Largillier R, Ferrero JM, Fontana X, Thyss A. Aromatase inhibition in male breast cancer patients: biological and clinical implications. Ann Oncol. 2010;21:1243-5. doi:10.1093/annonc/mdp450.

101. Wang L, Ellsworth KA, Moon I, Pelleymounter LL, Eckloff BW, Martin YN, et al. Functional genetic polymorphisms in the aromatase gene CYP19 vary 
the response of breast cancer patients to neoadjuvant therapy with aromatase inhibitors. Cancer Res. 2010;70:319-28. doi:10.1158/0008-5472.can-09-3224.

102. Flote VG, Furberg A, McTiernan A, Frydenberg H, Ursin G, Iversen A, et al. Gene variations in oestrogen pathways, CYP19A1, daily 17ss-estradiol and mammographic density phenotypes in premenopausal women. Breast Canc Res. 2014;16:499. doi:10.1186/s13058-014-0499-2.

103. Umetani M, Domoto H, Gormley AK, Yuhanna IS, Cummins CL, Javitt NB, et al. 27-Hydroxycholesterol is an endogenous SERM that inhibits the cardiovascular effects of estrogen. Nat Med. 2007;13:1185-92. doi:10.1038/nm1641.

104. Cali JJ, Russell DW. Characterization of human sterol 27-hydroxylase. A mitochondrial cytochrome $\mathrm{P}-450$ that catalyzes multiple oxidation reaction in bile acid biosynthesis. J Biol Chem. 1991;266:7774-8.

105. DuSell CD, Umetani M, Shaul PW, Mangelsdorf DJ, McDonnell DP. 27-hydroxycholesterol is an endogenous selective estrogen receptor modulator. Mol Endocrinol (Baltimore, Md). 2008;22:65-77. doi:10.1210/me.2007-0383.

106. Wu Q, Ishikawa T, Sirianni R, Tang H, McDonald JG, Yuhanna IS, et al. 27-Hydroxycholesterol promotes cell-autonomous, ER-positive breast cancer growth. Cell Rep. 2013;5:637-45. doi:10.1016/j.celrep.2013.10.006.

107. Burkard I, von Eckardstein A, Waeber G, Vollenweider P, Rentsch KM. Lipoprotein distribution and biological variation of 24S- and 27-hydroxycholesterol in healthy volunteers. Atherosclerosis. 2007;194:71-8. doi:10.1016/i.atherosclerosis.2006.09.026.

108. Popkin BM, Adair LS, Ng SW. The global nutrition transition: the pandemic of obesity in developing countries. Nutr Rev. 2012;70:3-21. doi:10.1111/j.1753-4887.2011.00456.x.

109. Darbre PD. Aluminium, antiperspirants and breast cancer. J Inorg Biochem. 2005;99:1912-9. doi:10.1016/j.jinorgbio.2005.06.001.

110. Darbre PD, Aljarrah A, Miller WR, Coldham NG, Sauer MJ, Pope GS. Concentrations of parabens in human breast tumours. J Appl Toxicol. 2004;24:5-13. doi:10.1002/jat.958.

111. Dieterich M, Stubert J, Reimer T, Erickson N, Berling A. Influence of lifestyle factors on breast cancer risk. Breast Care (Basel, Switzerland). 2014;9:407-14 doi:10.1159/000369571.

112. Rodrigues-Peres RM, Cadore S, Febraio S, Heinrich JK, Serra KP, Derchain SF, et al. Aluminum concentrations in central and peripheral areas of malignant breast lesions do not differ from those in normal breast tissues. BMC Cancer. 2013;13:104. doi:10.1186/1471-2407-13-104.

113. Barrington WE, Schenk JM, Etzioni R, Arnold KB, Neuhouser ML, Thompson $I M$, et al. Difference in association of obesity with prostate cancer risk between US African American and non-Hispanic white men in the Selenium and Vitamin E Cancer Prevention Trial (SELECT). JAMA Oncol. 2015. Ahead of print. doi:10.1001/jamaoncol.2015.0513.

114. Stanik S, Dornfeld LP, Maxwell MH, Viosca SP, Korenman SG. The effect of weight loss on reproductive hormones in obese men. J Clin Endocrinol Metab. 1981;53:828-32. doi:10.1210/jcem-53-4-828.

115. Pellitero S, Olaizola I, Alastrue A, Martinez E, Granada ML, Balibrea JM, et al. Hypogonadotropic hypogonadism in morbidly obese males is reversed after bariatric surgery. Obes Surg. 2012;22:1835-42. doi:10.1007/s11695-012-0734-9.

116. Blouin K, Veilleux A, Luu-The V, Tchernof A. Androgen metabolism in adipose tissue: recent advances. Mol Cell Endocrinol. 2009;301:97-103. doi:10.1016/j.mce.2008.10.035.

117. Tomlinson JW, Stewart PM. The functional consequences of 11 betahydroxysteroid dehydrogenase expression in adipose tissue. Horm Metab Res. 2002;34:746-51.

\section{Submit your next manuscript to BioMed Central and take full advantage of:}

- Convenient online submission

- Thorough peer review

- No space constraints or color figure charges

- Immediate publication on acceptance

- Inclusion in PubMed, CAS, Scopus and Google Scholar

- Research which is freely available for redistribution

Submit your manuscript at www.biomedcentral.com/submit 